mag. Dušana Findeisen

Logos - skupina samostojnih izobraževalcev

\title{
O KULTURI IN IZOBRAŽEVANJU ODRASLIH
}

\author{
Usposobljenost za kulturo
}

\begin{abstract}
V prašanje vloge kulture, na eni strani v življenju in izobraževanju odraslih, na drugi strani pa v razvoju družbe, se znova odpira tistim, ki razmišljamo, kako človeku in družbi odpreti poti. ${ }^{1} S$ tem $v$ zvezi se, že na samem začetku razprave, zastavijo tri vprašanja, na katera je moč odgovoriti le delno: (1) kaj je kultura, (2) kaj je usposobljenost za kulturo in (3) kako doseči usposobljenost za kulturo.
\end{abstract}

\section{KULTURA JE TISTO, KAR OSTANE, KO SMO VSE DRUGO POZABILI}

Ta misel je postala del francoske družbene mitologije, nekaj, kar se je globoko usidralo v vse, ki so zrasli v francoski kulturi. Kaže na to, kako težko je kulturo opredeliti, kajti kultura je živ proces in procese je danes vse težje ujeti v opredelitve. Tako je kultura morda sled, ki ostane $\mathrm{v}$ človeku po vsem tistem, kar je doživel, izkusil, spoznal. Je skupek dejanj, ki jih je človek opravil ali jih morda še bo. Je zapis družbenih okolij, v kate-

Kultura mora ostati del človekovega življenja in izobraževanja. rih se je gibal. Kultura, pravi Joffre Dumazedier, je lahko osebna in je lahko kultura družbenega okolja, skupnosti, ki jim človek pripada. Naloga izobraževanja odraslih pa je "človekovo osebno kulturo povezati s tisto kulturo, ki najbolje omogoča razvoj ${ }^{2}{ }^{2}$ Seveda gre pri tem za hkraten razvoj človeka in družbe.

Če je v nekaterih preteklih obdobjih izobraževanje odraslih lahko povečalo proizvodnost družbe ali države tako, da je bilo namenjeno predvsem delu, pa se zdi, da danes takšno izobraževanje odraslih ni dovolj. Še več, države, ki svojega razvoja ne bodo napotile tudi - ali predvsem - $\mathrm{k}$ doseganju usposobljenosti za kulturo svojih ljudi, države, kjer bo iz izobraževanja odraslih kultura izključena, se bodo same obsodile na manjšo ustvarjalnost in posledično tudi manjšo proizvodnost.

V svetu se družbena sestava spreminja. Nekoč smo govorili o družbenih slojih in razredih. Danes vse manj. Današnji svet pa se vse bolj deli zgolj na revne in bogate. Na tiste, ki imajo komaj dovolj znanja, da so lahko na voljo drugim kot nekakšna »vojska rezervistov« ali »storitveni proletariat «, in tiste, ki lahko strugo svojega življenja oblikujejo in usmerjajo. Slednji imajo dovolj splošne usposobljenosti za to, da sprejmejo odločitve in da gredo $v$ teh odločitvah do konca, da prevze-

Tisti, ki bodo usposobljeni za kulturo, bodo lahko zamenjali poklic, kadar bo potrebno. Tisti pa, ki bodo imeli zgolj delovna znanja in spretnosti za posamezna področja in poklice, ne pa tudi dovolj kulturne usposebljenosti, menjave poklica ne bodo prenesli in bodo izvrženi na rob družbenega razvoja.

majo odgovornost, da spreminjajo pot, kadar je potrebno. Ta splošna usposobljenost je zelo blizu temu, kar bi morda lahko poimenovali usposobljenost za kulturo ali s tujko kulturna kompetenca. ${ }^{3}$ Usposabljanje za kulturo je potemtakem pomembno s stališča posameznika, pa tudi skupnosti, če ta skupnost želi biti zdrava $\mathrm{v}$ tistem smislu, ki ga omenja Erich Fromm v svojem delu Zdrava družba.

Kulturo sociologi in etnologi pojmujejo kot »sistem duhovnih predstav«, ki naj posameznikom omogoči, da storijo dejanja ali se odzivajo na dejanja drugih. Tako sleherno naše obnašanje in ravnanje dobi pomen le znotraj družbene kode, torej znotraj sistema simbolov, prek katerih ljudje dojamemo in si z njimi razlagamo stvarnost. Kultura je potemtakem proces, ki se dogaja med nami in družbenim okoljem. Stvarnost, ki nas obdaja, zaznamo 
odvisno od tega, kako jo dojemajo in izražajo drugi ljudje. Gre za svet skupnih simbolov.

Kultura so tudi vrednote, ki jih imamo skupaj $\mathrm{z}$ drugimi ljudmi. Kultura je $\mathrm{v}$ tem, kako te vrednote razporedimo na svoji vrednostni lestvici, koliko nam pomenijo, kako te vrednote pogojujejo naše odločitve in obnašanje. Še več, kultura drži ogledalo družbenim, političnim, umetnostnim vrednotam družbe ali družb. Poleg duhovnih predstav in vrednot pa v kulturo sodijo predvsem »modeli obnašanja in delovanja ", kot pravijo sociologi. Kako kaj naredimo, kako kaj izvedemo, je odvisno od naše kulture in tega, kako smo izobraženi. ${ }^{4}$

Vprašanje, kaj je kultura, pa vendarle ostaja odprto. André Malraux trdi, da je to vse, kar se zgodi v človekovem življenju med rojstvom in smrtjo. Če je tako, potem moramo vedeti, da je ustvarjanje priložnosti za doživljanje kulture, prenašanje kulture ali usposabljanje za kulturo nekaj, kar moramo izobraževalci odraslih imeti nenehno v mislih.

Kako pomemben del našega sveta sta kultura in usposobljenost za kulturo, se zavemo predvsem takrat, ko izobražujemo odrasle, ki pripadajo marginaliziranim skupinam. Navadno govorimo, da gre pri takem izobraževanju predvsem za vzgojo in socializacijo in manj za prenašanje znanj. In vendar, kaj sta pravzaprav vzgoja in socializacija odraslega človeka? Vsekakor gre za preoblikovanje osebnosti. Morda bi lahko rekli, da gre pri tem tudi za počasno preoblikovanje posameznikove osebne kulture. Pri izobraževanju "funkcionalno nepismenih « ali, recimo temu raje "življenjsko nepismenih «, tistih, ki se s svojo kulturo ne morejo dobro vključiti v razvoj, se še posebej hitro zavemo, da je prenašanje znanja in spretnosti razmeroma preprosto v primerjavi s prenašanjem kulture. Slednje se zdi dolg proces, ki ga teže nadomestimo kot manjkajoča znanja in spretnosti. ${ }^{5}$ Pridobljena kultura pa je pomembna tudi zato, ker poveča posameznikovo predstavljivost ali usposobljenost za ustvarjanje predstav, kar je pogoj za dobro učenje. ${ }^{6}$

$\mathrm{V}$ predstave, $\mathrm{v}$ svet simbolov posameznega okolja pa se vtkejo tudi mnogi stereotipi. Druženje z izobraževalci odraslih in strokovnjaki iz različnih okolij kaže na to, kako se kljub globalizaciji javnih občil, ali morda prav zato, stereotipi vse bolj in $v$ vse večjem številu vgra-

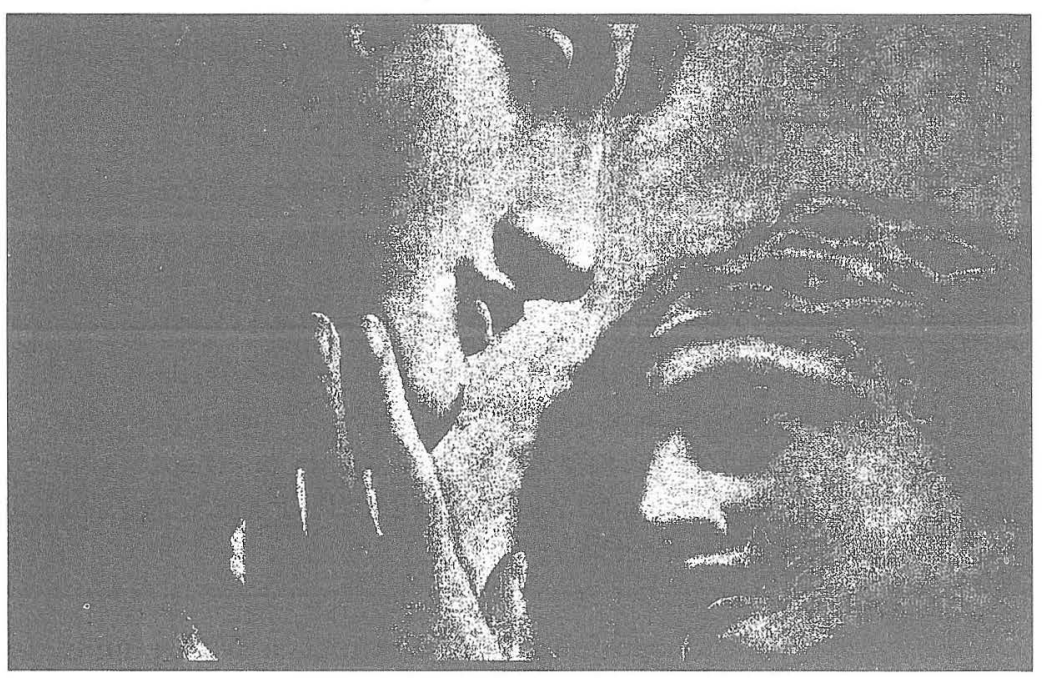

jujejo v naša razmišljanja. Zdi se, da je tako preprosto zato, ker se branimo pred nadaljnjim odkrivanjem in učenjem. Branimo se pred nenehnimi spremembami. Stereotipi tako postanejo vendarle nekakšna stalnica, del kulturnega okolja ali morda različnih kulturnih okolij, ki jim pripadamo. ${ }^{7}$ Bolj ko so ta okolja "na prepihu «, bolj so prepuščena zunanjim vplivom, tem večje je število posplošenih in nepreverjenih predstav.

\section{Usposabljanje za kulturo - nova naloga izobraževalcev odraslif.}

\section{INTERKULTURNOST IN TRANSKULTURNOST}

Vprašanji, ki se danes pogosto zastavljata $\mathrm{v}$ zvezi s kulturo v izobraževanju odraslih ali z usposabljanjem za kulturo oziroma kulture današnjega sveta, sta vprašanji interkulturnosti in transkulturnosti. Vse pogostejše je mnenje, da interkulturnost lahko povezujemo z bolj ustaljenimi in nespremenljivimi družbenimi okolji. Interkulturnost je pogojena $s$ tem, da obstajajo opredeljive, prepoznavne, pogosto geografsko opredeljene različne kulture, med katerimi se vzpostavljajo vezi. Morda jo povezujemo tudi z obdobjem, ko je bila globalizacija manj v zamahu. Takrat so pripadniki posameznih kultur svoja razmišljanja in občutja črpali iz opredeljenih zaledij naroda, teritorija, družbe.

Nasprotno pa je zdaj bolj govor o transkulturi. Gre za spretnosti, vedenja, znanja in občutja, ki jih črpamo tu in tam in jih lahko vgradimo v različna okolja, področja in kulture, povezane s posameznim geografskim ozemljem. Pogoj za uspešno razvijanje transkultur- 
Tisti, ki razmišljajo o kulturi današnjega sveta, razmišljajo tudi o umetnosti in o doseganju estetske presoje $v$ povezavi $z$ njo. O prvi pravijo, da drži ogledalo družbi in njeni razvitosti, saj položaj umetnosti odseva stanje $v$ družbi, pa tudi temelina načela, na katerih posamezna družba sloni. Družba, ki si npr. kot temeljno gibalo določi doseganje dobička, se bo umetnosti in kulturi poskušala odpovedati. Tako umetnost kot kultura, katere del umetnost je, namreč ne prinašata takojšnjih in oprijemljivih nasledkov, ki bi jih bilo mogoče količinsko opredeliti. Estetska presoja, ki se razvije skupaj z umetnostjo in kulturo, poveča ne samo sposobnost občutenja, marveč tudi kritičnega mišljenja. Tudi s tega stališča je usposabljanje za kulturo pomembno.

nosti je razvijanje skupnega sveta pojmov in konceptov, ki jih je mogoče zadovoljivo deliti $\mathrm{z}$ drugimi. Preden pa prevzamemo pojme in koncepte drugih, je dobro, da razmislimo o svojih lastnih. To še posebej velja za tista okolja, kjer posamezne generacije niso opravile svoje »prenašalske funkcije«, kot pravi Condorcet, kjer je prišlo do prekinitve s preteklostjo. V teh državah ali v teh okoljih ob-

\section{Šele kulturna usposobljenost omogoča ohranjanje in razvoj znanj.} staja nevarnost, da se $v$ njih brez prave usposobljenosti za kritični razmislek naselijo tuji pojmi, koncepti in vrednote. Razvoj nekega okolja pa vendarle temelji na njemu lastnem pojmovnem svetu. ${ }^{8}$

Razmišljanja o kulturi pripadnikov različnih okolij pokažejo tudi, kako globoke so nekatere razlike $\mathrm{v}$ dojemanju stvarnosti. Vprašanje razvijanja lastnih vrednot kot podlage za kritično sprejemanje drugih obvladuje predvsem nove države. Mednje sodi tudi Izrael z mnogimi na novo doseljenimi Judi, ki judaizem poznajo bolj obrobno, čeprav na judaizmu sloni velik del vrednot in kulturnih sporočil judovskega naroda. Nepoznavanje tradicionalnih vrednot, ki ga izkazujejo mlade generacije Judov, poglablja prepad med starimi in mladimi in slabi narod v celoti.

\section{KULTURNA USPOSOBLJENOST}

Pojma kulturne kvalificiranosti ali usposobljenosti s kulturo in pojem kulturne kompetence ali usposobljenosti za kulturo sta prešla v govorico vede o izobraževanju odraslih, zanimivo pa je, da ob poglobljenem razmisleku pripadnikov različnih okolij pridemo do toliko različnih opredelitev teh dveh pojmov, kot je ljudi, ki razmišljajo. Ena možnih opredeli- tev bi tako bila, da je usposobljenost za kulturo usposobljenost za sprejemanje in večanje znanja, sprejemanje in uporabo tehnologije, sprejemanje kritike in podajanje kritike, usposobljenost za povezovanje in sodelovanje $\mathrm{z}$ ljudmi. Prav tako je usposobljenost s kulturo in za kulturo tudi poglabljanje ustvarjalnosti, občutljivosti za umetnost, usposobljenosti za zaznavanje drugih in drugačnosti, usposobljenosti za uživanje življenja in radosti, usposobljenosti za premoščanje predsodkov. Današnja kultura je tudi obvladovanje sredstev javnega obveščanja, je usposobljenost za solidarnost, samozavest in sposobnost za poudarjanje lastnih dosežkov. Prav tako gre pri kulturni usposobljenosti tudi za intra-kulturni in trans-kulturni vidik, pri čemer je intrakulturna usposobljenost tista, ki jo potrebujemo znotraj posamezne kulture. Posamezna kultura pa je skupek kultur različnih ljudi, okolij in področij in povezava med njimi.

Če ta razmišljanja o kulturi in kulturni usposobljenosti, ki so se porodila na Salzburških pogovorih Avstrijske zveze ljudskih univerz v Salzburgu, primerjamo s tistimi, ki jih je Malcom Knowels navedel $\mathrm{v}$ povezavi $\mathrm{z}$ vzgojo odraslega človeka, spoznamo, da gre pravzaprav za podobne pojave. Morda bi, potemtakem, pojem kulturne usposobljenosti lahko približali bolje poznanim pojmom vzgojenosti in /ali socializiranosti odraslega človeka.

\section{KAKO DOSEČI USPOSOBLJENOST ZA KULTURO}

Glede na to, da ni povsem jasno, kaj kultura sploh je in kaj je usposobljenost za kulturo, tudi vprašanje, kako doseči usposobljenost za kulturo, ne bo našlo natančnega odgovora. Sprašujemo se, kako povezati dva enako utemeljena tokova, tj. globalizacijo in njej nasprotno lokalizacijo v kulturi. Kako slehernemu človeku zagotoviti dostop do usposobljenosti za kulturo, kajti le kultura mu bo pomagala, da bo zalogo različnih znanj, ki se danes hitro starajo, lahko ohranil in razvil.

Eno pa je vendarle jasno; kulture ne smemo ločiti od človeka. To se namreč zgodi v vseh oblikah sodobnega suženjstva. To se je zgodilo v industrijskem obdobju z ločitvijo družinskega od poklicnega življenja, z ločitvijo dela od prostega časa. To se je zgodilo v nekaterih totalitarnih državah. Posledično bi lahko re- 
kli, da lahko sleherno usposabljanje odraslih, pa naj bo še tako ozko namenjeno pridobivanju spretnosti ali delovnih znanj, spremenimo $\mathrm{v}$ povečanje usposobljenosti za kulturo. Pri tem je pomembno, da ozke spretnosti in znanja umestimo v širši sistem kulture. Ta sistem daje slehernemu izseku iz človekovega življenja ali človekovim prizadevanjem širše in globlje razsežnosti. Tudi če izobraževanje ni namenjeno usposabljanju ali izobraževanju za kulturo, lahko gremo dlje od učinkovitega prenašanja znanj. Lahko razmislimo o tem, kako se to znanje povezuje $\mathrm{z}$ drugimi znanji, kako se povezuje s človekovim življenjem in življenjem skupnosti, ki jim posameznik pripada. Lahko spodbudimo čustveno spoznavanje. Vsakokrat, ko se v izobraževanju odraslih obračamo k človeku, vsakokrat, ko je naše razmerje do znanj podrejeno našemu razmerju do človeka, ki se uči, in njegovemu razmerju z njim samim ter svetom, povečujemo usposobljenost za kulturo. V svetu, ki se povezuje, kjer se srečujejo in povezujejo kulture, pa bodo potrebni tudi tolmači kultur. Tolmači kulturnih pojmov in konceptov. Izobraževanje odraslih naj bi k temu pripomoglo.

\section{SKLEPNE MISLI}

Kultura je proces, ki, kot smo dejali poprej, ne dopušča opredelitev. Sleherno dokončno mnenje o kulturi lahko takoj ovržemo ali obogatimo z novimi. Prav tako je z usposobljenostjo za kulturo, ki nastopa kot eden ključnih pojmov $\mathrm{v}$ izobraževanju odraslih. Tako kot opredelitve tudi sklepi k tem razmišljanjem niso mogoči. Če bi do sklepov vendarle prišli, ne bi bili nič drugega kot razmišljanje, ki bi ga dodali k poprejšnjim. Pa vendar, morda le zaključno opozorilo. Človek, skupnost ali država niso nikoli dovolj revni, da bi lahko privolili v to, da živijo brez kulture. Revščina ne more biti izgovor za to, da svoja prizadevanja posvetimo le doseganju takojšnjih ekonomskih ciljev. Kultura mora biti vpletena $\mathrm{v}$ vsa naša prizadevanja, pa tudi $\mathrm{v}$ izobraževanje in usposabljanje odraslih.

\section{LITERATURA}

Chambers, Iain: Migration, Kultur, Indentitat, Tubingen, 1996.

Dumazedier, J.: Vers une civilisation du loisir?, Editions du Seuil, Paris, 1962.
Findeisen, D.: "Med poklicnim in humanističnim izobraževanjem ...« v: Andragoška spoznanja, št. 1, 1996, str. 49-52.

Le Vine, R.A..: Culture, Behaviour and Personality, Chicago, 1973

Malewska, H., Tap, P.: La socialisation de l'enfance a l'adolescence, Puf, Paris, 1991. New York, 1990.

Poster, C., Kruger, A.: Community Education in the Western World, Routledge.

Sainsaulieu, R.: L'identité au travail, Presses de la fondation nationale des sciences politiques, Paris, 1977.

Welsch, W. : "Transkulturalitat. Lebensformen nach der Aufloesung der Kultur ", v.: Luger, K. in Renger, R.: Dialog der Kulturen. Die Multikulturelle Geselschaft und die Medien. Wien, 1994.

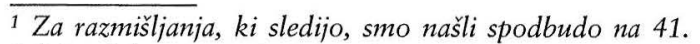
Salzburških pogovorih Avstrijse zveze ljudskih univerz na temo "Kulturno izobraževanje - kultura v izobraževanju«. ${ }_{2}$ Človekov razvoj je možen le $v$ odnosu z okoljem. In v tem je morda tudi ključno vprašanje funkcionalne pismenosti. Namreč, kako kulturo človeka, ki v našem okolju ni funkcionaino pismen, ki se v življenju »ne znajde«, ki svojih vprašanj ne zna rešiti in se vrti v začaranem krogu, kako to kulturo povezati s kulturo okolja. Tistega okolja, ki se mora uvrstiti med druga, pogosto tekmovalno razpoložena okolja, ki zahtevajo znanje, nenehno učenje, pa tudi mnoge lastnosti, povezane z neodvisnostio in podjetnostjo.

${ }^{3}$ Usposobljenost za kulturo je ena t. i. ključnib usposobljenosti posameznika, to je tistih, ki povečajo vse druge usposobljenosti. Morda podobno kot to storijo pismenost in numeričnost ali funkcionalna pismenost.

${ }^{4}$ Ko sem npr. pred davnimi leti v našem okolju izročila svojo diplomsko nalogo, likovno opremljeno po vzoru nalog francoskib univerz, je bilo to zunaj priznanib modelov obnašanja in ravnanja, zunaj obstoječe kulture. Usposobljenost za kulturo pomeni tudi obvladovanje modelov obnašanja in delovanja, ki so v okolju sprejemlivi.

${ }^{5}$ Pri izobraževanju sprevodnikov za mednarodne vlake je bilo to spoznanje najbolj pomembno. Naučiti sprevodnike posameznih ubeseditev, nasmeha ali prijazne drže glave in pogleda, ni bilo posebej težko. Zataknilo se je pravzaprav pri tem, kako jim omogočiti boljše razumevanje vedenja potnikov različnih narodnosti, omogočiti jim, da bi poznali vsaj nekaj zgodovine železnic ali posameznih evropskib postaj. Londonska Victoria station ali dunajska postaja Franc Jožef sta bili zanje pousem neumestljiva pojma. Povezati ti dve imeni s posameznimi obdobji v zgodovini ni bilo preprosto.

${ }^{6}$ Moč človekove predstavliivosti se npr. močno poveča $z$ branjem. Predstavljivost pa je tudi del spoznavnosti, ki jo $v$ izobraževanju odraslih želimo razvijati.

${ }^{7} S$ posameznimi novimi evropskimi državami se povezujejo predstave o vojni, neredu, zaostalosti, nerazvitosti. $\mathrm{Za}$ razbijanje teh stereotipov je potrebna dodatna usposobljenost, ki posamezniku omogoči, da vstopi $v$ svet simbolov drugega človeka. Te stereotipe je mogoče zamajati le tako, da dobro predvidimo poti razmišljanja drugega človeka, da poznamo sistem njegovih vrednot.

${ }^{8}$ Vrednote, ki jih izobraževalci odraslih danes zaznamo pri nekaterih poklicnih skupinah udeležencev, so pravzaprav izposojene ali vsiljene vrednote. To so informiranost $v$ nasprotju z učenjem, preučevanjem, ustvarjanjem, obvladovanje postopkov besedne umetnosti $v$ nasprotju $z$ obvladovanjem kulture, ki jo pogojuje, lepo oblačenje brez globljega vedenja o kulturi ali kulturah, ki jih načini oblačenja izražajo. Gre zvečine za ameriške vrednote. 